\title{
Available nitrogen is the key factor influencing soil microbial functional gene diversity in tropical rainforest
}

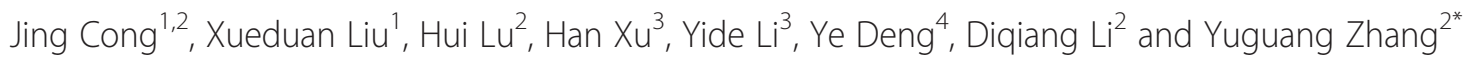

\begin{abstract}
Background: Tropical rainforests cover over $50 \%$ of all known plant and animal species and provide a variety of key resources and ecosystem services to humans, largely mediated by metabolic activities of soil microbial communities. A deep analysis of soil microbial communities and their roles in ecological processes would improve our understanding on biogeochemical elemental cycles. However, soil microbial functional gene diversity in tropical rainforests and causative factors remain unclear. GeoChip, contained almost all of the key functional genes related to biogeochemical cycles, could be used as a specific and sensitive tool for studying microbial gene diversity and metabolic potential. In this study, soil microbial functional gene diversity in tropical rainforest was analyzed by using GeoChip technology.
\end{abstract}

Results: Gene categories detected in the tropical rainforest soils were related to different biogeochemical processes, such as carbon $(C)$, nitrogen $(N)$ and phosphorus $(P)$ cycling. The relative abundance of genes related to $C$ and $P$ cycling detected mostly derived from the cultured bacteria. $C$ degradation gene categories for substrates ranging from labile $C$ to recalcitrant $C$ were all detected, and gene abundances involved in many recalcitrant $C$ degradation gene categories were significantly $(P<0.05)$ different among three sampling sites. The relative abundance of genes related to $N$ cycling detected was significantly $(P<0.05)$ different, mostly derived from the uncultured bacteria. The gene categories related to ammonification had a high relative abundance. Both canonical correspondence analysis and multivariate regression tree analysis showed that soil available $\mathrm{N}$ was the most correlated with soil microbial functional gene structure.

Conclusions: Overall high microbial functional gene diversity and different soil microbial metabolic potential for different biogeochemical processes were considered to exist in tropical rainforest. Soil available $\mathrm{N}$ could be the key factor in shaping the soil microbial functional gene structure and metabolic potential.

Keywords: Tropical rainforest, GeoChip, Microbial functional gene diversity, Microbial metabolic potential, Available nitrogen

\section{Background}

Tropical rainforests account for only $7 \%$ of the Earth's land surface, yet they cover over $50 \%$ of all known plant and animal species and provide a variety of key resources and ecosystem services to humans, including food, drinking water, timber and medicines [1-3]. Soil microbial communities are expected to be particularly complex under

\footnotetext{
* Correspondence: yugzhang@sina.com.cn

${ }^{2}$ Institute of Forestry Ecology, Environment and Protection, and the Key Laboratory of Forest Ecology and Environment of State Forestry Administration, Chinese Academy of Forestry, Beijing 100091, China Full list of author information is available at the end of the article
}

tropical rainforests [4]. A deep analysis of soil microbial communities and their roles in ecological processes would improve our understanding of biogeochemical elemental cycles in the tropical rainforests [5].

Recent years, there are many reports about microbial community structure based on 16S rRNA sequences or single functional groups in different environments $[6,7]$. In the Amazon and other tropical rainforest environments, some studies of soil microbial community composition were mainly examined based on the microbial phylogenetic diversity [8-10]. However, integrated understanding of environmental microbial biogeographic patterns and their 
ecosystem function is difficult [11]. Therefore, it is needed to explore the microbial functional gene diversity and metabolic potential to detect environmental microbial metabolic processes [7]. GeoChip 5.0, containing almost all of the key functional genes related to biogeochemical cycles, can be used as a specific and sensitive tool for studying microbial gene diversity and metabolic potential [7, 12-14]. Correlations between environmental microbial communities and ecosystem processes have successfully been used in different ecosystems [7, 12-14].

Nitrogen concentration has an important effect on soil microbial community structure and function with further consequences for ecosystem processes $[15,16]$. In the last several decades, human activities of deforestation, fossil fuel and fertilizer uses have affected the nitrogen $(\mathrm{N})$ cycling and changed $\mathrm{N}$ deposition rate $[17,18]$, resulting in increased emissions of $\mathrm{N}$ at least fourfold over the last century [19]. Elevated atmospheric $\mathrm{N}$ deposition is generally considered to significantly alter species composition, nutrient imbalance, nitrate leaching, loss of biodiversity [20]. A number of experiments have been performed to investigate effects of increased input of $\mathrm{N}$ on soil microbial community of tropical forests. These studies showed that $\mathrm{N}$ enrichment would alter soil microbial community composition and provide feedbacks on soil $C$ pools $[19,20]$. However, the microbial ecological process related to $\mathrm{N}$ cycling and the key controlling factors in tropical rainforest are unclear. Therefore, it is necessary to discuss microbial functional gene diversity, especially involved in $\mathrm{N}$ cycling, and corresponding influencing factors.

Jianfengling Forest Area (JFA) $\left(18^{\circ} 23^{\prime}-18^{\circ} 52^{\prime} \mathrm{N}, 108^{\circ}\right.$ $\left.36^{\prime}-109^{\circ} 05^{\prime} \mathrm{E}\right)$ covering $600 \mathrm{~km}^{2}[21]$, is situated in southwestern Hainan Island, which is a global biodiversity hotspot area [22], and is one of a few areas in China where primary tropical rainforest is preserved. The forest area is heavily affected by $\mathrm{N}$ deposition, with over $25 \mathrm{~kg} \mathrm{~N} \mathrm{ha}^{-1} \mathrm{yr}^{-1}$ deposited on Hainan Island from 1990 to 2003 [23]. In this study, we selected three sampling sites in the primary tropical rainforest in Jianfengling and analyzed the soil microbial functional gene diversity and metabolic potential using GeoChip 5.0. The aims were to determine (i) soil microbial functional gene diversity and metabolic potential in primary tropical rainforest soils; (ii) major environmental factors in governing the soil microbial functional gene diversity.

\section{Results}

\section{Plant communities and soil properties}

According to (Additional file 1: Table S1 and S2), plant dominant species and plant species diversity were distinctly different among three sampling sites. The JFL-3 and JFL-1 had the highest and lowest Shannon-Weaver index, respectively. The PCA showed that three sampling sites were well separated from each other (Additional file 2: Figure S1), indicated that they had distinct plant community structure. Soil $\mathrm{pH}$ was acidity $(\mathrm{pH}<5.0)$, and soil moisture was over $30 \%$ in three sampling sites. For the soil nutrient properties, these sites were also different. The JFL-3 had the highest contents in soil total nitrogen and available nitrogen. Therefore, plant communities and soil properties had differences among three sampling sites.

\section{Microbial functional gene diversity in tropical rainforest soil} To understand soil microbial functional gene diversity, the detected number of genes, alpha diversity index (Shannon and Simpson index) and normalized signal intensity of microbial functional gene families were analyzed. The total number of genes detected was 27,887 , ranged from 22,902 to 27,363 in the three sampling sites (Table 1), which accounted for $45.90 \%, 39.83 \%$ and $47.58 \%$ of the total gene probes of GeoChip 5.0 in JFL-1, JFL-2 and JFL3 , respectively. The mean number of detected genes and alpha diversity index were the lowest in JFL-2 (19,469 and 9.85, respectively). The DCA of all detected genes showed that soil microbial functional communities were well separated from three sampling sites (Fig. 1), indicated that distinct microbial functional gene structure existed in the three sampling sites.

Of the 393 functional gene categories based on GeoChip 5.0, $89.06 \%$ was detected. The detected functional gene categories were related to different biogeochemical processes, such as $\mathrm{C}$ cycling, $\mathrm{N}$ cycling, $\mathrm{S}$ cycling, $\mathrm{P}$ cycling, organic remediation, metal homeostasis and virulence (Additional file 2: Figure S2). These functional gene categories were distinctly different among these sampling sites. JFL-2 had significantly $(P<0.05)$ higher functional gene abundances of $\mathrm{C}$ cycling, $\mathrm{P}$ cycling and $\mathrm{S}$ cycling genes than these in JFL-1 and JFL-3. For function gene abundances involved in $\mathrm{N}$ cycling, metal Homeostasis, organic remediation and virulence, JFL-2 was significantly $(P<0.05)$ lower than in JFL-1 and JFL-3. To better understand microbial functional gene diversity and metabolic potential, key gene categories involved in $\mathrm{C}, \mathrm{N}$ and $\mathrm{P}$ cycling were selected and analyzed.

Table 1 Gene number and diversity indices for GeoChip data in three sampling sites

\begin{tabular}{llll}
\hline Parameter & JFL-1 & JFL-2 & JFL-3 \\
\hline No. of detected genes & 26392 & 22902 & 27363 \\
$\begin{array}{l}\text { Mean No. of detected } \\
\text { genes }^{\mathrm{a}}\end{array}$ & $24497 \pm 1355 \mathrm{a}$ & $19469 \pm 3347 \mathrm{~b}$ & $25625 \pm 954 \mathrm{a}$ \\
Shannon index $^{\mathrm{a}}$ & $10.09 \pm 0.06 \mathrm{a}$ & $9.85 \pm 0.19 \mathrm{~b}$ & $10.14 \pm 0.04 \mathrm{a}$ \\
Simpson index $^{\mathrm{a}}$ & $23930 \pm 1286 \mathrm{a}$ & $19110 \pm 3228 \mathrm{~b}$ & $25037 \pm 932 \mathrm{a}$ \\
\hline
\end{tabular}

${ }^{a}$ The data is the mean value and standard error for eight plots. The same lowercase letters within the same row in the footnote mean the difference was not significant, whereas the difference was significant $(P<0.05)$ 


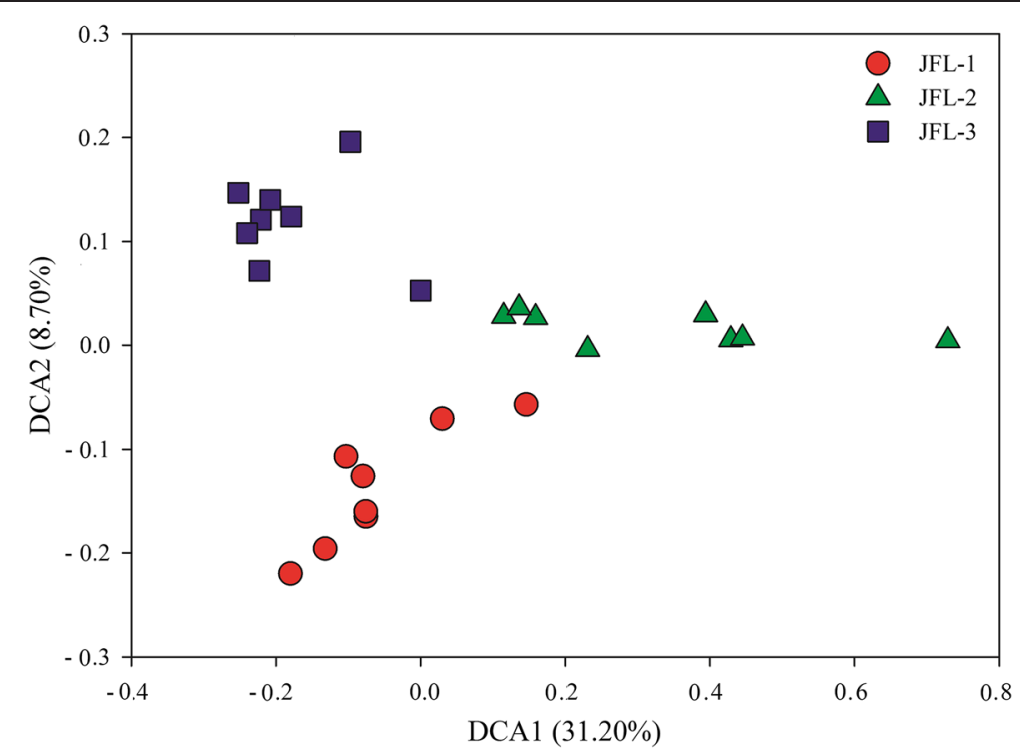

Fig. 1 Detrended correspondence analysis (DCA) of soil microbial community based on functional gene data. The DCA was analyzed based on the relative signal intensity of functional genes $(n=24)$

\section{Microbial functional genes involved in C cycling}

Key functional gene categories involved in carbon degradation, carbon fixation, methane production and methane oxidation were detected in all sampling sites. A total of 8,578 genes involved in carbon degradation were detected in these sampling sites, and most of the functional gene $(95.44 \%)$ involved in carbon degradation was derived from cultured bacteria. Among the three sampling sites, the functional genes related to recalcitrant carbon degradation encoding cellobiase, exoglucanase, chitinase, glyoxal oxidase, lignin peroxidase, manganese peroxidase and phenol oxidase were significantly $(P<0.05)$ different (Fig. 2$)$. For example, the abundance of genes encoding cellobiase was significantly lower $(P<0.05)$ in JFL-2 compared to the other two sampling sites. However, there were no significant differences for functional gene abundance related to labile carbon (starch and hemicellulose) degradation among the three sampling sites, except for labile carbon degradation gene pullulanase, which was significantly $(P<0.05)$ higher in JFL-2 than in JFL-1 and JFL-3.

A total of 3,131 and 228 genes involved in carbon fixation and methane cycling were detected in these sampling sites, respectively. The key genes (FBPase, rubisco, $C O D H$, and FTHFS) involved in carbon fixation were detected in all sampling sites and most of the detected genes $(92.14 \%)$ were derived from cultured bacteria. The abundance of genes involved in the Calvin cycle was significantly $(P<0.05)$ lower in JFL-2 than in JFL-1 and JFL-3 (Additional file 2: Figure S3). For the reductive acetyl-CoA pathway, the gene abundance of $\mathrm{CODH}$ was significantly higher in JFL-2 than in JFL-1 and JFL-3, yet FTHFS was significantly lower in J FL-2 than in JFL-1 and JFL-3 (Additional file 2: Figure S3). For methane cycling, $78.51 \%$ of the detected genes were derived from uncultured bacteria. Genes ( $m c r A, m m o X$ and $p m o A$ ) involved in methane production and oxidation were detected in all sampling sites (Additional file 2: Figure S4). The abundance of $m c r A$ genes involved in methane production in JFL-2 was significantly $(P<0.05)$ higher than in JFL-1 and JFL-3, and the abundance of $p m o A$ genes involved in methane oxidation in JFL-2 was significantly lower $(P<0.05)$ compared to the other two sampling sites.

These results showed that all of the metabolic processes soil bacteria mediated of related to carbon degradation, carbon fixation and methane cycle existed in these tropical rainforest soils, and some key functional gene abundances were significantly different $(P<0.05)$, which could lead to the differences of soil microbial metabolic potential among these sampling sites.

\section{Microbial functional genes involved in $\mathbf{N}$ cycling}

A total of 3,624 genes involved in $\mathrm{N}$ cycling were detected in these sampling sites, including ammonification, assimilatory $\mathrm{N}$ reduction, denitrification, nitrification, dissimilatory $\mathrm{N}$ reduction and $\mathrm{N}$ fixation, and $60.13 \%$ of these genes were derived from uncultured bacteria. Gene abundances related to assimilatory $\mathrm{N}$ reduction, denitrification, dissimilatory $\mathrm{N}$ reduction, nitrification, and $\mathrm{N}$ fixation were significantly lower in JFL-2 than these in JFL-1 and JFL-3 $(P<0.05$; Fig. 3). These results showed that almost all the metabolic processes related to $\mathrm{N}$ cycling were present in 


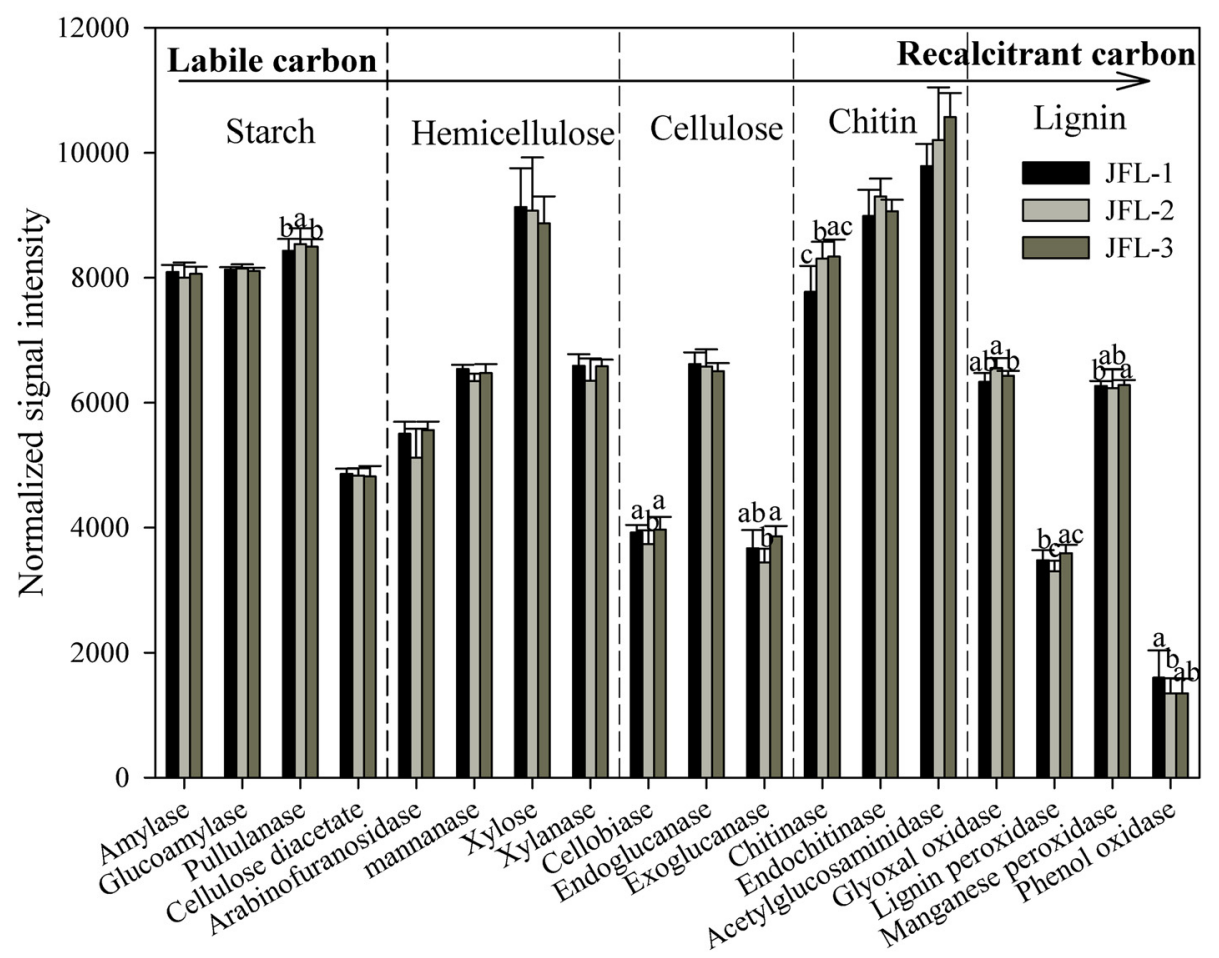

Fig. 2 The normalized signal intensity of the detected key genes involved in carbon degradation. The complexity of carbon is presented in order from labile to recalcitrant. The signal intensity for each functional gene category is the average of the total signal intensity from all the replicates $(n=8)$. All data are presented as mean \pm SE (error bars). Different letters indicated statistical differences at a $P$ value of $<0.05$ among sampling sites by one-way ANOVA

these tropical rainforest soils, while the metabolic potential could be discrepant among three sampling sites in the tropical rainforest soils.

\section{Microbial functional genes involved in P cycling}

Total of 1,208 functional genes involved in P cycling were detected in these sampling sites, including polyphosphate degradation (polyphosphatase gene, $p p x$ ), polyphosphate synthesis (polyphosphate kinase gene, $p p k$ ) and phytic acid hydrolysis (phytase gene, phy), and most of the detected genes $(92.47 \%)$ were derived from cultured bacteria. The abundances of $p p x$ and phy genes in JFL-2 were significantly higher $(P<0.05)$ than in JFL-1 and JFL-3, while the abundance of $p p k$ in JFL-2 was significantly lower $(P<0.05)$ than in JFL-1 and JFL-3 (Additional file 2: Figure S5). These results showed that all the metabolic processes related to $\mathrm{P}$ cycling were presented in these tropical rainforest soils, and metabolic potential for $\mathrm{P}$ cycling might be different in these three sampling sites.

\section{Relationship between soil microbial functional gene structure and environmental variables}

Canonical correspondence analysis (CCA) was used to analyze the relationship between the microbial functional gene structure and the major environmental variables (Fig. 4), resulting in a significant model at a confidence level of $P=0.043$. The first axis was the most negatively and significantly correlated with soil available $\mathrm{N}$, followed by total phosphorus. The second axis was the most positively and significantly correlated with plant diversity, followed by total nitrogen (Fig. 4a). Therefore, N, especially soil available $\mathrm{N}$, was the most correlated with soil microbial communities at the functional gene level.

Multivariate regression tree (MRT) analysis is well suitable for complex ecological datasets with highorder interactions in a visualized tree [24]. For the MRT analysis, dissimilarity was used to split data into two groups based on one of the environmental variables. Each split was described graphically as a branch in a tree. Each branch was labeled with response environmental variable that was placed in that branch. We compared the results of MRT using the whole GeoChip data and environmental variables (Fig. 4b). In this tree, soil microbial communities at the functional gene level were first split by soil available $\mathrm{N}$, followed by plant species diversity. According to the relationship between environmental factors and microbial functional gene structure, soil available $\mathrm{N}$ could be the major factors 


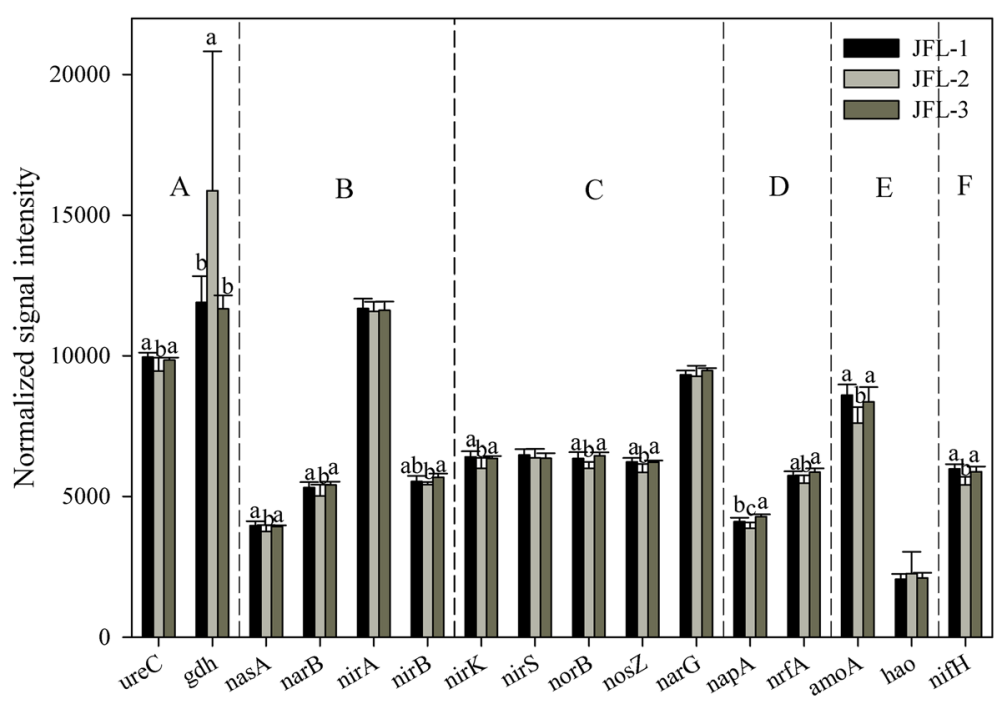

Fig. 3 The normalized signal intensity of the detected key genes involved in nitrogen cycling. The signal intensity for each functional gene category is the average of the total signal intensity from all the replicates $(n=8)$. (a). Ammonification, including gdh for glutamate dehydrogenase and ure $C$ encoding urease; (b). Assimilatory $\mathrm{N}$ reduction, including nas $A$ encoding nitrate reductase, narB, nirA and nirB encoding dissimilatory nitrite reductase; (c). Denitrification, including narG for nitrate reductase, nirS and nirK for nitrite reductase, norB for nitric oxide reductase, and nosZ for nitrate reductase; (d). Dissimilatory N reduction, including napA for nitrate reductase, and nrfA for c-type cytochrome nitrite reductase; (e). Nitrification, including $a m o A$ encoding ammonia monooxygenase, hao for hydroxylamine oxidoreductase; (f). N fixation, including nifH encoding nitrogenase. All data are presented as mean \pm SE (error bars). Different letters indicated statistical differences at a $P$ value of $<0.05$ among sampling sites by one-way ANOVA

in shaping the microbial functional structure in these sampling sites, followed by plant species diversity, similar to the CCA result.

\section{Discussion}

GeoChip-based data provided a lot of information on different biogeochemical processes, which contributed to explore soil microbes potentially effects on soil enzyme activities or components. In this study, we analyzed soil microbial functional gene structure using GeoChip 5.0, and detected microbial functional gene categories, which could represent the in situ metabolic potential to some degree [7]. Soil carbon cycling is one of the most important and complex processes in biogeochemical cycles [25]. In our study, the gene number of functional genes related to carbon cycling accounted for over $40 \%$ of all genes detected, suggested that these tropical rainforest soils might have a strong metabolic potential for carbon cycling.

Humid tropical forest soils have the fastest degradation rates of plant litter [26], conducted by soil microorganisms with highly efficient carbon degrading ability. For example, cellulose enzyme activity related to cellulose gene variants $[27,28]$ and oxidizable organic carbon was significantly linked to the relative abundance of genes involved in cellulose, hemicellulose and starch degradation [7]. Carbon degradation gene categories for substrates ranging from labile carbon (starch and hemicellulose) to recalcitrant carbon (cellulose, chitin and lignin) were all detected in three sampling sites. The relative abundance of most functional genes involved in recalcitrant carbon degradation (e.g., cellulose, chitin and lignin) was distinctly different among the three sampling sites, which indicated that the metabolic potential of degrading recalcitrant carbon for soil microbial communities was discrepant from three sampling sites in tropical rainforest. In addition, the relative abundance of genes related to active carbon degradation was not significantly different among the sampling sites, except for pullulanase gene, which indicated that soil microbes related to labile carbon degradation could execute similar carbon substrates. Therefore, tropical rainforest soils may contain a series of complex, adaptable microbial metabolic communities involved in degradation of different substrates.

P cycling played a key role in changing the species composition, diversity and productivity in tropical rainforests. In this study, we detected a high relative abundance of $p h y, p p k$ and $p p x$ genes (Additional file 2: Figure S5). Microbial mineralization of phytate, which is the most abundant compound containing organic $\mathrm{P}$ in soil, is a key process for recycling $\mathrm{P}$ by phytases in the biosphere [29]. At present, four classes of phytases have been defined in terrestrial organisms: histidine acid phosphatase, cysteine phytase, purple acid phosphatase and $\beta$-propeller phytase $[29,30]$. ppk encodes polyphosphate kinase, which could be used to reflect the potential for biological $\mathrm{P}$ removal [31]. ppx encodes exopolyphosphatase, catalyzing the 


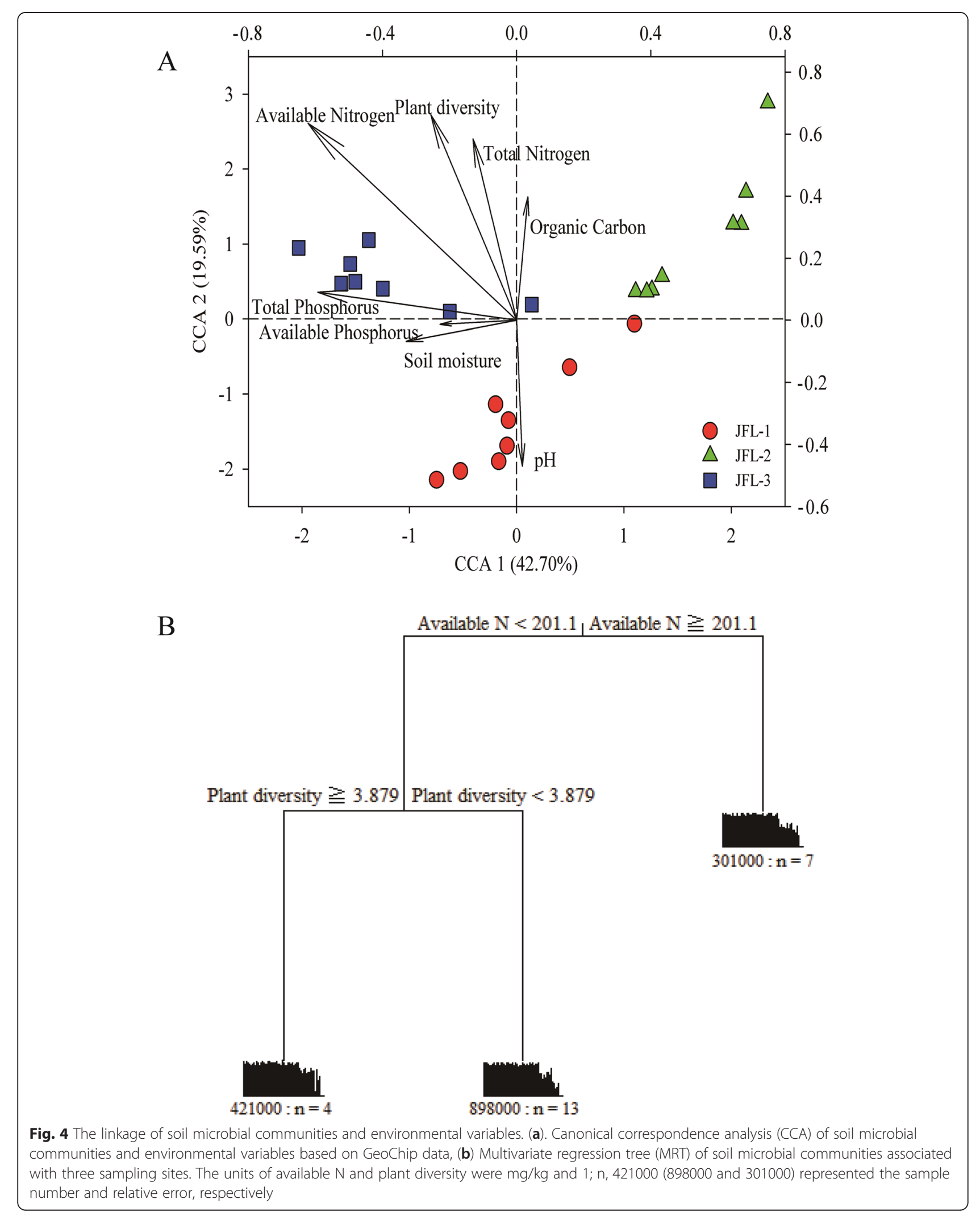


polyphosphate transfer to phosphate. The tropical rainforests are considered to be P limited [32], since elevated atmospheric $\mathrm{N}$ deposition may further lead to $\mathrm{P}$ limitation [20]. Experimental P additions in tropical rainforests have revealed that microbial utilization for the labile fractions of soil organic $C$ could be restricted or controlled by soil $P$ [33]. Moreover, P-induced variation in microbial communities could cause corresponding shifts in the functional and metabolic potentials of the communities, resulting in a change in decomposition rates [15]. The CCA result also indicated that soil total phosphorus played a key role in soil microbial communities (Fig. 4a). In general, a highly efficient bacterial community structure and metabolic potential was formed to adapt to P limitation in the tropical rainforest.

Soil microbes are the major drivers of soil $\mathrm{N}$ cycling, including $\mathrm{N}$ fixation, nitrification, denitrification, ammonification, assimilatory $\mathrm{N}$ reduction and dissimilatory $\mathrm{N}$ reduction [34]. In our study, we found a high metabolic potential for nitrate reduction, especially a high relative abundance of the narG gene, which could be caused by the high rate of $\mathrm{N}$ deposition in forest soils [20]. Some tropical forests were observed to be $\mathrm{N}$ saturated and exhibited a high nitrate leaching rate in the region of high $\mathrm{N}$ deposition region [35], particularly the oldgrowth forest [36]. Nitrogen from ammonium $\left(\mathrm{NH}_{4}{ }^{+}\right)$is the dominant $\mathrm{N}$ form in bulk deposition, however, the increasing rate for $\mathrm{N}$ deposition is the highest from nitrate $\left(\mathrm{NO}_{3}{ }^{-}\right)$[36]. To decrease $\mathrm{NO}_{3}{ }^{-}$concentrations in soil, a strong metabolic potential for denitrification is needed. High soil $\mathrm{N}_{2} \mathrm{O}$ fluxes were observed (mean $\mathrm{N}_{2} \mathrm{O}$ emission rate of $2.21 \mathrm{~kg} \mathrm{~N}-\mathrm{N}_{2} \mathrm{O} \mathrm{ha}{ }^{-1} \mathrm{yr}^{-1}$ in the wet season) in the JFL [37], which were significantly higher than temperate spruce forest in Germany, tropical rainforests in Australia and Indonesia, and un-grazed semi-arid steppe in China [38, 39]. Therefore, microbial communities from the tropical rainforest had a highly efficient metabolic potential in satisfying the soil $\mathrm{N}$ cycling.

In this study, we detected almost all the functional gene categories involved in N cycling based on GeoChip 5.0. There were distinct differences in the relative abundance of different functional gene categories, indicated that metabolic potentials for different processes in $\mathrm{N}$ cycling were distinctly different, probably caused by $\mathrm{N}$ limiting factors in the ecosystem. $\mathrm{N}$ is the primary factor of limiting plant growth in tropical rainforests, and strong competition has been observed between plants and microorganisms [40]. Nitrogen concentration played a key role in soil microbial community structure and function with further consequences for ecosystem processes $[15,16]$. $\mathrm{N}$ additions could directly restrict microbial growth [41], relative abundance [42] and microbial functional diversity [43]. Krashevska et al. found that the soil microbial biomass and community structure were strongly altered in response to even moderate changes in $\mathrm{N}$ inputs in the soils of tropical rainforests, indicating that the potential was changed in causing key ramifications of the whole ecosystem including plant growth and litter decomposition through nutrient additions [19]. Many microbial enzyme activities were changed by $\mathrm{N}$ condition [44]. For example, cellulase activity of decaying oak litter was stimulated by $\mathrm{N}$ addition, but lignin-degrading activity was significantly decreased [45]. Also, $\mathrm{N}$ saturation could also lower soil $\mathrm{pH}$, resulting in leaching of calcium and magnesium and mobilization aluminum, and then experiencing aluminum toxicity [46]. In our study, both CCA and MRT analyses indicated that soil available nitrogen was the most important factors in influencing soil microbial community structure at the functional gene level.

In addition, microbial communities mediated soil key processes involved in carbon and nitrogen cycling, which potentially represented a mechanistic relationship between plant species diversity and ecosystem function. The availability of growth-limiting resources, such as organic compounds in dead leaves and roots (i.e., detritus) that can generate cellular energy [47], influences the composition of microbial communities [48]. Due to different biochemical composition and changes in plant diversity, plant species changes the production and range of organic compounds in detritus that influence the composition and function of heterotrophic microbial communities. Zak DR, et al. conducted a long-term field manipulation to determine that the biomass, respiration and abundance of soil microbial communities significantly increased with higher plan species diversity [49]. The PCA indicated that plant communities were distinct among three sampling sites (Additional file 2: Figure S1). Therefore, plant communities could have an important control in microbial community structure, verified by CCA and MRT analyses.

\section{Conclusions}

In summary, we analyzed the soil microbial functional gene diversity and metabolic potential in the tropical rainforests of JFL by GeoChip technology. The metabolic processes soil bacteria mediated of related to $C$, $\mathrm{N}, \mathrm{P}$ cycling existed in these tropical rainforest soils, and some key functional gene abundances were significantly different $(P<0.05)$, which could lead to the differences of soil microbial metabolic potential among these sampling sites. A high relative abundance of genes related to ammonification, denitrification and $\mathrm{N}$ fixation were found in these soils. Both CCA and MRT showed that soil microbial functional gene structure was mainly influenced by soil available $\mathrm{N}$ and plant diversity. These results indicated the metabolic potential for microbial communities could acclimatize to acid tropical rainforest soils. 


\section{Methods}

\section{Site and sampling}

The study sites were located on JFA (Additional file 2: Figure S6) and botanically diverse with over 2,800 plant species [46]. The main forest types include tropical semi-deciduous monsoon forest, tropical evergreen monsoon forest, tropical montane rainforest, and mossy forest on the mountain peak. The climate is characterized by tropical monsoons with a wet season from May to October and a dry season from November to April. The mean annual temperature is $24.5{ }^{\circ} \mathrm{C}$, with an annual rainfall of $1,600-2,600 \mathrm{~mm}[50]$.

In the JFA, we selected three sampling sites (JFL-1, JFL-2 and JFL-3) in the tropical rainforest of wellprotected primary forest types. In three sampling sites, there existed different plant dominant species, which were Gironniera girosuba, Blastus blascoch and Pinanga pinabavi in JFL-1, Gironniera girosuba, Cryptocarya crypchine and Prismatomeris pristetr in JFL-2, Neolitsea Gironniera girosuba, Cryptocarya crypchine and Neolelli in JFL-3, respectively (Additional file 1: Table S1). The mean altitude was $872 \mathrm{~m}, 945 \mathrm{~m}$, and $992 \mathrm{~m}$ in JFL-1, JFL-2 and JFL-3, respectively.

These soil samples were collected in March 2012. In each sampling site, eight plots of $20 \mathrm{~m} \times 20 \mathrm{~m}$ were carried out with a plot interval between adjacent sampling plots, total of 24 plots sampled (Additional file 2: Figure S6). Soil samples were randomly taken from each plot at the depth of $10 \mathrm{~cm}$ by multiple sampling methods, and ten to fifteen points in each plot were collected, and mixed as a plot soil sample. Roots and stones were removed from samples. Soil samples were stored at $4{ }^{\circ} \mathrm{C}$ for soil physicochemical analysis, and at $-80{ }^{\circ} \mathrm{C}$ for DNA analysis, respectively.

\section{Plant diversity and soil nutrient properties}

All trees with diameter at breast height $(1.3 \mathrm{~m}$; DBH) of $\geq 1.0 \mathrm{~cm}$ were surveyed to profile plant communities. The plant Shannon-Weaver index of each plot was calculated according to the surveyed plant data (Additional file 1: Table S2). Soil moisture (MO) was measured by gravimetrical methods. Soil pH was measured with a $\mathrm{pH}$ meter by soil water (1:2.5 mass: volume soil and water suspension). Soil total nitrogen (N) content, total phosphorus (P) content, available nitrogen $(\mathrm{N})$ content, total organic carbon $(\mathrm{C})$ content and $\mathrm{pH}$ were analyzed as previously described [51].

\section{Microbial DNA extraction, purification and quantification}

As previously described [52], soil microbial DNA was extracted directly from $5 \mathrm{~g}$ combined soil by freezegrinding mechanical lysis. DNA quality and concentration were evaluated using a FLUOstar Optima microplate reader
(BMG Labtech, Jena, Germany), based on the ratios of 260 $\mathrm{nm} / 280 \mathrm{~nm}$ and $260 \mathrm{~nm} / 230 \mathrm{~nm}$.

\section{GeoChip hybridization and data analysis}

GeoChip was used to analyze soil microbial functional gene diversity and metabolic potential. GeoChip 5.0 contained about 57,504 50-mer oligonucleotide probes, covered 393 gene categories, and involved in microbial (protists, fungi, bacteria and archaea) biogeochemical cycles of carbon, nitrogen, phosphorus, sulfur, etc. (http://ieg.ou.edu/entrance.html). Soil microbial DNA purification, labeling, GeoChip hybridization and signal reading were performed according to previous methods [7, 13]. GeoChip data were further analyzed using the following steps: (i) genes detected in only two out of eight samples from the same sampling site were removed; (ii) signals were normalized by dividing by the mean value of total signal intensity of 24 samples.

\section{Statistical analysis}

The alpha diversity of soil microbial communities was conducted by the Shannon-Weaver index and Simpson's index based on the GeoChip data. The normalized signal intensity of each functional gene family was used as the gene relative abundance [12]. Statistical differences were analyzed by a one-way analysis of variance (ANOVA) at a significance level of $P<0.05$. Principal component analysis (PCA) was used to evaluate the differences of plant communities among sampling sites. Detrended correspondence analysis (DCA) was used to evaluate the differences of soil microbial communities among sampling sites, carried out by using the 'vegan' package. Canonical correspondence analysis (CCA) and multivariate regression tree (MRT) were used to explain the relationship of soil microbial community structure and environmental variables in a visualized tree, carried out by using the 'vegan' and 'mvpart' package, respectively. All the data analyses were performed in R (v. 2.13.1).

\section{Availability}

The microarray data discussed in this manuscript have been deposited in NCBI's Gene Expression Omnibus and are accessible through GEO Series accession number GSE6917 (http://www.ncbi.nlm.nih.gov/geo/query/ acc.cgi?acc=GSE69171).

\section{Additional files}

Additional file 1: Table S1. The general characters of three sampling sites in the tropical rainforest. Table S2. The environmental factors of three sampling sites in the tropical rainforest. (DOC $40 \mathrm{~kb}$ )

Additional file 2: Figure S1. The principal component analysis of plant community structure in three sampling sites. Figure S2. The normalized signal intensity of detected genes from different gene 
categories. Figure S3. The normalized signal intensity of detected key genes involved in carbon fixation. Figure S4. The normalized signal intensity of detected key genes involved in methane cycle. Figure S5. The normalized signal intensity of the detected key genes involved in phosphorus cycle. Figure S6. Study sites in Jianfengling Forest Area. (DOCX $1154 \mathrm{~kb}$ )

\section{Competing interests}

The authors declare that they have no competing interests.

\section{Authors' contributions}

JC carried out the sampling collecting, data analysis and the manuscript preparation. YGZ carried out the lab design, sampling collecting, data analysis. HL participated in the sampling collecting and biogeochemical data analysis. $\mathrm{HX}$ and YDL carried out the plant survey and soil nutrients analysis. YD participated in the GeoChip data analysis. XDL and DQL participated in the lab design and the manuscript revision. All authors read and approved the final manuscript.

\section{Authors' information}

$\mathrm{JC}$ is the doctor of School of Minerals Processing and Bioengineering in Central South University, Changsha, China.

XDL is the professor of School of Minerals Processing and Bioengineering in Central South University, Changsha, China.

$\mathrm{HL}$ is the master student in Institute of Forestry Ecology, Environment and Protection, and the Key Laboratory of Forest Ecology and Environment of State Forestry Administration, the Chinese Academy of Forestry, Beijing, China.

$H X$ is the associated professor in Institute of Tropical Forestry, Chinese Academy of Forestry, Guangzhou, China.

YDL is the professor in Institute of Tropical Forestry, Chinese Academy of Forestry, Guangzhou, China.

YD is the professor in Research Center for Eco-Environmental Science, Chinese Academy of Sciences, Beijing, China

$\mathrm{DQL}$ is the professor in Institute of Forestry Ecology, Environment and Protection, and the Key Laboratory of Forest Ecology and Environment of State Forestry Administration, the Chinese Academy of Forestry, Beijing, China.

YGZ is the associated professor in Institute of Forestry Ecology, Environment and Protection, and the Key Laboratory of Forest Ecology and Environment of State Forestry Administration, the Chinese Academy of Forestry, Beijing, China.

\section{Acknowledgements}

This research was supported by the public welfare project of the national scientific research institution (Grant No. CAFYBB2011004, CAFRIFEEP201101), China, and the National Biological Specimens and Resources Sharing Platform in Nature Reserve (Grant No. 2005DKA21404), and the Strategic Priority Research Program of the Chinese Academy of Sciences (Grant No. XDB15010302), and also supported by Graduate student research innovation project in Hunan province (CX2014B095). We also gratefully acknowledge Dr. Guangliang Li for helping survey the plant plots.

\section{Author details}

'School of Minerals Processing and Bioengineering, Central South University, Changsha 410083, China. ${ }^{2}$ Institute of Forestry Ecology, Environment and Protection, and the Key Laboratory of Forest Ecology and Environment of State Forestry Administration, Chinese Academy of Forestry, Beijing 100091, China. ${ }^{3}$ Institute of Tropical Forestry, Chinese Academy of Forestry, Guangzhou 510520, China. ${ }^{4}$ Research Center for Eco-Environmental Science, Chinese Academy of Sciences, Beijing 100085, China.

\section{Received: 10 January 2015 Accepted: 21 July 2015 Published online: 20 August 2015}

\section{References}

1. Lewis SL, Lloyd J, Sitch S, Mitchard ET, Laurance WF. Changing ecology of tropical forests: evidence and drivers. Annu Rev Ecol Evol Syst. 2009;40:529-49.

2. Sitch S, Huntingford C, Gedney N, Levy P, Lomas M, Piao S, et al. Evaluation of the terrestrial carbon cycle, future plant geography and climate-carbon cycle feedbacks using five Dynamic Global Vegetation Models (DGVMs). Glob Chang Biol. 2008;14(9):2015-39.

3. Vittor AY, Pan W, Gilman RH, Tielsch J, Glass G, Shields T, et al. Linking deforestation to malaria in the Amazon: characterization of the breeding habitat of the principal malaria vector, Anopheles darlingi. Am J Trop Med Hyg. 2009;81(1):5-12.

4. Russo SE, Legge R, Weber KA, Brodie EL, Goldfarb KC, Benson AK, et al. Bacterial community structure of contrasting soils underlying Bornean rain forests: Inferences from microarray and next-generation sequencing methods. Soil Biol Biochem. 2012;55:48-59.

5. Fierer N, Leff JW, Adams BJ, Nielsen UN, Bates ST, Lauber CL, et al. Cross-biome metagenomic analyses of soil microbial communities and their functional attributes. Proc Natl Acad Sci. 2012;109(52):21390-5.

6. Bru D, Ramette A, Saby N, Dequiedt S, Ranjard L, Jolivet C, et al. Determinants of the distribution of nitrogen-cycling microbial communities at the landscape scale. ISME J. 2010;5(3):532-42.

7. Zhang Y, Cong J, Lu H, Yang C, Yang Y, Zhou J, et al. An Integrated Study to Analyze Soil Microbial Community Structure and Metabolic Potential in Two Forest Types. PLoS One. 2014;9(4), e93773.

8. da C Jesus E, Marsh TL, Tiedje JM, de S Moreira FM. Changes in land use alter the structure of bacterial communities in Western Amazon soils. ISME J. 2009;3(9):1004-11.

9. Pereira RM, Silveira EL, Scaquitto DC, Pedrinho EAN, Val-Moraes SP, Wickert E, et al. Molecular characterization of bacterial populations of different soils. Braz J Microbiol. 2006;37(4):439-47.

10. Quirino BF, Pappas GJ, Tagliaferro AC, Collevatti RG, Neto EL, da Silva MRS, et al. Molecular phylogenetic diversity of bacteria associated with soil of the savanna-like Cerrado vegetation. Microbiol Res. 2009;164(1):59-70.

11. Green JL, Bohannan BJ, Whitaker RJ. Microbial biogeography: from taxonomy to traits. Science. 2008;320(5879):1039-43.

12. Bai S, Li J, He Z, Van Nostrand JD, Tian Y, Lin G, et al. GeoChip-based analysis of the functional gene diversity and metabolic potential of soil microbial communities of mangroves. Appl Microbiol Biotechnol. 2013;97(15):7035-48.

13. He Z, Xu M, Deng $Y$, Kang $S$, Kellogg $L$, Wu L, et al. Metagenomic analysis reveals a marked divergence in the structure of belowground microbial communities at elevated CO2. Ecol Lett. 2010;13(5):564-75.

14. Xu M, He Z, Deng Y, Wu L, Van Nostrand JD, Hobbie SE, et al. Elevated CO2 influences microbial carbon and nitrogen cycling. BMC Microbiol. 2013;13(1):124

15. Ramirez KS, Craine JM, Fierer N. Consistent effects of nitrogen amendments on soil microbial communities and processes across biomes. Glob Chang Biol. 2012;18(6):1918-27.

16. Wei C, Yu Q, Bai E, Lü X, Li Q, Xia J, et al. Nitrogen deposition weakens plant-microbe interactions in grassland ecosystems. Glob Chang Biol. 2013;19(12):3688-97.

17. Tian H, Wang S, Liu J, Pan S, Chen H, Zhang C, et al. Patterns of soil nitrogen storage in China. Global Biogeochemical Cycles. 2006; 20(1).

18. Dentener F, Drevet J, Lamarque J, Bey I, Eickhout B, Fiore A, et al. Nitrogen and sulfur deposition on regional and global scales: a multimodel evaluation. Global Biogeochemical Cycles. 2006; 20(4).

19. Krashevska V, Sandmann D, Maraun M, Scheu S. Moderate changes in nutrient input alter tropical microbial and protist communities and belowground linkages. ISME J. 2014;8(5):1126-34.

20. Liu L, Zhang T, Gilliam FS, Gundersen P, Zhang W, Chen H, et al. Interactive effects of nitrogen and phosphorus on soil microbial communities in a tropical forest. PLoS One. 2013;8(4), e61188.

21. Chan S. Directory of important bird areas in China (mainland): key sites for conservation. Cambridge: BirdLife International; 2009.

22. Myers N, Mittermeier RA, Mittermeier CG, Da Fonseca GA, Kent J. Biodiversity hotspots for conservation priorities. Nature. 2000;403(6772):853-8.

23. Lü C, Tian H. Spatial and temporal patterns of nitrogen deposition in China: synthesis of observational data. Journal of Geophysical Research: Atmospheres (1984-2012). 2007; 112(D22).

24. De'Ath G. Multivariate regression trees: a new technique for modeling species-environment relationships. Ecology. 2002;83(4):1105-17.

25. Nielsen U, Ayres E, Wall D, Bardgett R. Soil biodiversity and carbon cycling: a review and synthesis of studies examining diversity-function relationships. Eur J Soil Sci. 2011;62(1):105-16.

26. Parton W, Silver WL, Burke IC, Grassens L, Harmon ME, Currie WS, et al. Global-scale similarities in nitrogen release patterns during long-term decomposition. Science. 2007;315(5810):361-4. 
27. Reeve JR, Schadt CW, Carpenter-Boggs L, Kang S, Zhou J, Reganold JP. Effects of soil type and farm management on soil ecological functional genes and microbial activities. ISME J. 2010;4(9):1099-107.

28. Yergeau E, Kang S, He Z, Zhou J, Kowalchuk GA. Functional microarray analysis of nitrogen and carbon cycling genes across an Antarctic latitudinal transect. ISME J. 2007:1 (2):163-79.

29. Lim BL, Yeung P, Cheng C, Hill JE. Distribution and diversity of phytatemineralizing bacteria. ISME J. 2007;1 (4):321-30.

30. Chu H-M, Guo R-T, Lin T-W, Chou C-C, Shr H-L, Lai H-L, et al. Structures of $<i>$ Selenomonas ruminantium</i > Phytase in Complex with Persulfated Phytate: DSP Phytase Fold and Mechanism for Sequential Substrate Hydrolysis. Structure. 2004;12(11):2015-24.

31. McMahon KD, Dojka MA, Pace NR, Jenkins D, Keasling JD. Polyphosphate kinase from activated sludge performing enhanced biological phosphorus removal. Appl Environ Microbiol. 2002;68(10):4971-8.

32. Krashevska V, Maraun M, Ruess L, Scheu S. Carbon and nutrient limitation of soil microorganisms and microbial grazers in a tropical montane rain forest. Oikos. 2010;119(6):1020-8.

33. Cleveland CC, Townsend AR, Schmidt SK. Phosphorus limitation of microbial processes in moist tropical forests: evidence from short-term laboratory incubations and field studies. Ecosystems. 2002;5(7):0680-91.

34. Lindsay EA, Colloff MJ, Gibb NL, Wakelin SA. The abundance of microbial functional genes in grassy woodlands is influenced more by soil nutrient enrichment than by recent weed invasion or livestock exclusion. Appl Environ Microbiol. 2010;76(16):5547-55.

35. Fang Y, Yoh M, Koba K, Zhu W, Takebayashi Y, Xiao Y, et al. Nitrogen deposition and forest nitrogen cycling along an urban-rural transect in southern China. Glob Chang Biol. 2011;17(2):872-85.

36. Liu X, Zhang Y, Han W, Tang A, Shen J, Cui Z, et al. Enhanced nitrogen deposition over China. Nature. 2013;494(7438):459-62.

37. Bai Z, Yang G, Chen H, Zhu Q, Chen D, Li Y, et al. Nitrous oxide fluxes from three forest types of the tropical mountain rainforests on Hainan Island, China. Atmos Environ. 2014;92:469-77.

38. Luo G, Kiese R, Wolf B, Butterbach-Bahl K. Effects of soil temperature and moisture on methane uptakes and nitrous oxide emissions across three different ecosystem types. Biogeosci Discuss. 2013;10(1):927-65.

39. Purbopuspito J, Veldkamp E, Brumme R, Murdiyarso D. Trace gas fluxes and nitrogen cycling along an elevation sequence of tropical montane forests in Central Sulawesi, Indonesia. Global Biogeochem Cycles. 2006; 20(3).

40. Geisseler D, Horwath WR, Joergensen RG, Ludwig B. Pathways of nitrogen utilization by soil microorganisms-a review. Soil Biol Biochem. 2010:42(12):2058-67.

41. Treseder KK. Nitrogen additions and microbial biomass: A meta-analysis of ecosystem studies. Ecol Lett. 2008;11(10):1111-20.

42. Frey SD, Knorr M, Parrent JL, Simpson RT. Chronic nitrogen enrichment affects the structure and function of the soil microbial community in temperate hardwood and pine forests. For Ecol Manage. 2004;196(1):159-71.

43. Calderón FJ, Jackson LE, Scow KM, Rolston DE. Microbial responses to simulated tillage in cultivated and uncultivated soils. Soil Biol Biochem. 2000;32(11):1547-59.

44. Michel K, Matzner E. Response of enzyme activities to nitrogen addition in forest floors of different C-to-N ratios. Biol Fertil Soils. 2003;38(2):102-9.

45. Carreiro M, Sinsabaugh R, Repert D, Parkhurst D. Microbial enzyme shifts explain litter decay responses to simulated nitrogen deposition. Ecology. 2000;81(9):2359-65.

46. Zeng Q, Li Y, Chen B, Wu Z, Zhou G. Tropical Forest Ecosystems Research and Management. Beijing: China Forestry Publishing House; 1997. in Chinese.

47. Smith J, Paul E. The significance of soil microbial biomass estimations. Soil Biochem. 1990;6:357-96.

48. Tilman D. Secondary succession and the pattern of plant dominance along experimental nitrogen gradients. Ecol Monogr. 1987;57(3):189-214.

49. Zak DR, Holmes WE, White DC, Peacock AD, Tilman D. Plant diversity, soil microbial communities, and ecosystem function: are there any links? Ecology. 2003;84(8):2042-50.

50. Zou F-S, Chen G-Z, Yang Q-F, Li Y-D. Bird species richness along an elevational gradient in a forest at Jianfengling, Hainan Island, China. Zool Stud. 2012;51:362-71.

51. Lu R. Soil and agricultural chemistry analysis. Beijing: China Agricultural; 2000.

52. Zhou J, Bruns MA, Tiedje JM. DNA recovery from soils of diverse composition. Appl Environ Microbiol. 1996;62(2):316-22.

\section{Submit your next manuscript to BioMed Central and take full advantage of:}

- Convenient online submission

- Thorough peer review

- No space constraints or color figure charges

- Immediate publication on acceptance

- Inclusion in PubMed, CAS, Scopus and Google Scholar

- Research which is freely available for redistribution

Submit your manuscript at www.biomedcentral.com/submit 